\title{
In vitro evaluation of new molecule fungicides against Rhizoctonia solani Kuhn causing sheath blight disease in rice
}

\author{
Vikash Kumar Yadav , V.P. Chaudhary, S.K. Singh, Manish Kumar Maurya, S.P. Vishwakarma and S.N. Rahul \\ Department of Plant Pathology, Acharya Narendra Deva University of Agriculture and Technology, Kumarganj, Ayodhya-224229,
} Uttar Pradesh, India

\section{Article Info}

Article history

Received 25 June 2021

Revised 13 August 2021

Accepted 14 August 2021

Published Online 30 December 2021

\section{Keywords}

In vitro

Rhizoctonia solani Kuhn

Sheath blight

Management

\begin{abstract}
Sheath blight disease caused by Rhizoctonia solani Kühn is a major disease of rice which causes an economic yield loss. Chemical control measures are already utilized for the management of the disease but continuous use of same fungicide develops resistance in the pathogen. That's why newer molecule has been used from time-to-time. The present study was undertaken to evaluate the different new molecule of fungicides against $R$. solani at 0.1 per cent and 0.2 per cent concentration in in vitro condition. The results were found that complete inhibition was recorded under treatment propineb, propiconazole, hexaconazole and carbendazim while in kresoxim methyl $(89.04 \%, 94.16 \%)$, tebuconazole + trifloxystrobin $(93.70 \%, 96.50 \%)$ and mancozeb $(80.50 \%, 88.34 \%)$ at 0.1 and 0.2 per cent concentration, respectively after 4 day of inoculation. After 8 days, treatment propineb, propiconazole, hexaconazole and carbendazim completely inhibited the mycelial growth of the fungus while in kresoxim methyl $(87.58 \%, 90.40 \%)$, tebuconazole + trifloxystrobin $(90.18 \%, 96.47 \%)$ and mancozeb $(77.97 \%, 86.13 \%)$ at 0.1 and 0.2 per cent concentration, respectively.
\end{abstract}

\section{Introduction}

Rice (Oryza sativa L.) is a monocotyledonous annual grass, belonging to family Poaceae and the genus Oryza. Globally, over 3 billion people have rice as their staple food, and accounts for 50 to 80 per cent of their daily calorie intake (Delseny et al., 2001). Rice is the most important and staple food crop for more than two third populations of the India and more than 65 per cent population of the world. It plays a pivotal role in our national food security and it is a means of livelihood for millions of rural household. To meet the global rice demand, it is predicted that about 114 million tons of additional milled rice is required (Mahantesh et al., 2018).

Rice crop is affected by number of biotic and abiotic factors. Among biotic factors, fungal diseases are the major constraints in rice production. Sheath blight is one of the most important and widely distributed diseases in all the rice growing regions of the world and causing considerable losses in grain yield (Pathak et al., 2020). Paracer and Chahal (1963) reported disease for the first time in India from Gurdaspur, Punjab. Now, it was reported from almost every part of the world where rice is cultivated and causes up to $50 \%$ yield loss (Chahal et al., 2003). Visible symptoms of the disease are formation of lesions on the sheath, plant lodging, and presence of empty grains. Large lesions formed on infected sheaths of lower leaves may lead to softness of the stem thereby initiating stem lodging (Wu et al., 2012). The disease is also known by other

Corresponding author: Mr. Vikash Kumar Yadav

Department of Plant Pathology, Acharya Narendra Deva University of Agriculture and Technology, Kumarganj, Ayodhya-224229, Uttar Pradesh, India

E-mail: rvikashyadav@gmail.com

Tel.: +91-9565919002

Copyright (c) 2021 Ukaaz Publications. All rights reserved.

Email: ukaaz@yahoo.com; Website: www.ukaazpublications.com name, i.e., snake skin disease and rotten foot stalk as per appearance of the symptom of disease (Molla et al., 2020).

When one per cent increase in sheath blight severity resulted in grain yield loss of $0.38 \%$ (Singh et al., 2015). The complex genetic nature of resistance to sheath blight and genetic variability of the pathogen increases the difficulty in developing resistant host genotypes, as well as in effectively deploying available tolerant cultivars (Meena et al., 2013). However, at present, there is no known rice variety which is either immune or possesses high degree of resistance to sheath blight disease in Uttar Pradesh, India (Adhipathi et al., 2013). In the absence of suitable resistant donors, fungicides are the only option to manage the diseases. Earlier recommended fungicides such as zineb do not provide control disease significantly (Mahantesh et al., 2018). Present investigation was done to evaluate the different fungicides at different concentration against $R$. solani causing sheath blight of rice in lab condition.

\section{Materials and Methods}

2.1 In vitro evaluation of fungicides against the Rhizoctonia solani Kuhn

\subsubsection{Isolation of pathogen}

The infected plant part showing typical sheath blight symptoms were collected from Student's Instructional Farm of ANDUAT, Kumarganj, Ayodhya. The samples were brought to the laboratory of Department of Plant Pathology for isolation. A infected symptom were cut into small pieces with healthy part and sterilized with 1 per cent sodium hypochlorite for surface sterilization. Then, the samples were washed three times with the distilled water. The bits were place in the Petri disc containing PDA and incubated at $25 \pm 2^{\circ} \mathrm{C}$. 
Pathogen was identified on the basis of their cultural and morphological characters.

\subsubsection{Evaluation of fungicides against $R$. solani}

Efficacy of seven fungicides at different concentrations was evaluated against $R$. solani by using poisoned food technique (see Table 1). A series of concentration as 0.1 and 0.2 per cent of all fungicides were made on the basis of active ingredient. Required amount of each fungicide were inoculated with $R$. solani, was incorporated aseptically in autoclaved PDA at 0.1 and 0.2 per cent and incubated at $28 \pm 2^{\circ} \mathrm{C}$ for 8 days. The mycelial growth was measured after 4 and 8 days of incubation. Petri plate plates without fungicide served as control. A completely randomized design (CRD) was adopted for this experiment with three replications. The details of fungicides are given in Table 1. The fungal mycelial growth was measured in each plate and per cent inhibition in mycelial growth was calculated over check. The per cent inhibition of mycelial growth was calculated by using formula given by Vincent (1947) and the data were analyzed statistically using completely randomized design.

$$
\text { Growth inhibition } \%=\frac{\mathrm{C}-\mathrm{T}}{\mathrm{C}} \times 100
$$

where,

$$
\begin{aligned}
& \mathrm{I}=\text { Percent inhibition in mycelia growth } \\
& \mathrm{C}=\text { Average colony } / \text { fungal growth diameter in control } \\
& \mathrm{T}=\text { Average colony } / \text { fungal growth diameter in treatment }
\end{aligned}
$$

Table 1: List of fungicides used in experiment

\begin{tabular}{|c|l|l|l|l|}
\hline S.No. & Fungicide & Trade name & Formulation & Name of company \\
\hline 1. & Kresoxim methyl & Ergon & $44.3 \mathrm{SC}$ & Tata Rallis \\
\hline 2. & Propineb & Antracol & $70 \mathrm{WP}$ & Bayer \\
\hline 3 & $\begin{array}{l}\text { Tebuconazole 50\%+ } \\
\text { Trifloxystrobin 25\% }\end{array}$ & Nativo & $75 \mathrm{WG}$ & Bayer \\
\hline 4. & Propiconazole & Tilt & $25 \mathrm{EC}$ & Syngenta \\
\hline 5. & Hexaconazole & Contaf plus & $5 \mathrm{EC}$ & Tata \\
\hline 6. & Mancozeb & Dithane M-45 & $75 \mathrm{WP}$ & Shree ram \\
\hline 7. & Carbendazim & Bavistin & $50 \mathrm{WP}$ & Orbit \\
\hline
\end{tabular}

\subsection{Statistical analysis}

The data recorded on radial growth were statistically analysed using completely randomized design (CRD) by WASP 1.0 (Web Agri Stat Package 1.0).

\section{Results}

\subsection{In vitro evaluation fungicides against $R$. solani}

All seven fungicides, tebuconazole 50\% + trifloxystrobin 25\% (Nativo) carbendazim 50\%WP (Bavistin), kresoxime methyl $44.3 \%$ SC (Ergon), propineb 70\% WP (Antracol), hexaconazole 5 EC (Contaf plus), mancozeb 75 WP (Dithan M-45) and propiconazole 25 EC (Tilt) exhibited varying level of efficacy against $R$. solani for mycelial growth inhibition observed at 4 and $8^{\text {th }}$ day after inoculation.

\subsubsection{Effect on mycelial growth}

\subsubsection{After 4 day}

The result presented in Table 2 and Plate 1 revealed that the minimum mycelial growth $(4.50,2.50 \mathrm{~mm})$ was recorded in tebuconazole + trifloxystrobin followed by kresoxim methyl (7.83, $4.17 \mathrm{~mm})$ and mancozeb $(13.93,8.33 \mathrm{~mm})$ while no mycelial growth were found in propineb, propiconazole, hexaconazole and carbendazim. All the treatment were significantly superior over control $(71.47 \mathrm{~mm})$ at 0.1 and 0.2 per cent concentration.

\subsubsection{After 8 day}

The results presented in Table 3 and Plate 1 revealed that the minimum mycelia growth $(8.83,3.17 \mathrm{~mm})$ was recorded in tebuconazole + trifloxystrobin followed by kresoxim methyl (11.17, $8.64 \mathrm{~mm})$ and mancozeb $(19.83,12.48 \mathrm{~mm})$ while no radial growth was found in propineb, propiconazole, hexaconazole and carbendazim. All the treatments were significantly superior over control $(90.00 \mathrm{~mm})$ at 0.1 and 0.2 per cent concentration.

\subsubsection{Effect on per cent inhibition}

\subsubsection{After 4 day}

The results tabulated in Table 2 and Plate 1 showed that propineb, propiconazole, hexaconazole and carbendazim was found to be highly effective and gives complete inhibition at the concentration of 0.1 and $0.2 \%$ while tebuconazole + trifloxystrobin give 93.70 , $96.50 \%$ inhibition of mycelia growth followed by kresoxim methyl $(89.04,94.16 \%)$ and mancozeb $(80.50,88.34 \%)$ inhibition at 0.1 and 0.2 per cent concentration.

\subsubsection{After 8 days}

The results tabulated in Table 3 and Figures 1 and 2 showed that propineb, propiconazole, hexaconazole and carbendazim were found to be highly effective and gives complete inhibition at the concentration of 0.1 and $0.2 \%$, while tebuconazole + trifloxystrobin give $90.18,96.47 \%$ inhibition of mycelia growth, followed by kresoxim methyl $(87.58,90.40 \%)$ and mancozeb $(77.96,86.13 \%)$ inhibition was recorded at 0.1 and 0.2 per cent concentration. 
Table 2: Efficacy of fungicides (after 4 day) at different concentrations against $R$. solani

\begin{tabular}{|c|c|c|c|c|c|}
\hline \multirow[t]{2}{*}{ S.No. } & \multirow[t]{2}{*}{ Fungicides } & Radial growth (mm) & \multirow[t]{2}{*}{ Inhibition \% } & Radial growth (mm) & \multirow[t]{2}{*}{ Growth inhibition \% } \\
\hline & & Conc. (0.1\%) & & Conc. $(0.2 \%)$ & \\
\hline $\mathrm{T}_{1}$ & Kresoxim methyl & $7.83(16.24)$ & 89.04 & $4.17(11.75)$ & 94.16 \\
\hline $\mathrm{T}_{2}$ & Propineb & $0(0.28)$ & 100 & $0(0.28)$ & 100 \\
\hline $\mathrm{T}_{3}$ & $\begin{array}{l}\text { Tebuconazole }+ \\
\text { Trifloxystrobin }\end{array}$ & $4.50(12.19)$ & 93.70 & $2.50(9.09)$ & 96.50 \\
\hline $\mathrm{T}_{4}$ & Propiconazole & $0(0.28)$ & 100 & $0(0.28)$ & 100 \\
\hline $\mathrm{T}_{5}$ & Hexaconazole & $0(0.28)$ & 100 & $0(0.28)$ & 100 \\
\hline $\mathrm{T}_{6}$ & Mancozeb & $13.93(21.94)$ & 80.50 & $8.33(16.74)$ & 88.34 \\
\hline $\mathrm{T}_{7}$ & Carbendazim & $0(0.28)$ & 100 & $0(0.28)$ & 100 \\
\hline $\mathrm{T}_{8}$ & Control & $71.47(57.76)$ & - & $71.47(57.76)$ & - \\
\hline & $\mathrm{CD}(p=0.01)$ & 3.11 & & 3.10 & \\
\hline & $\mathbf{C V}$ & 9.38 & & 10.58 & \\
\hline
\end{tabular}

() figures in parentheses are transformed angular value

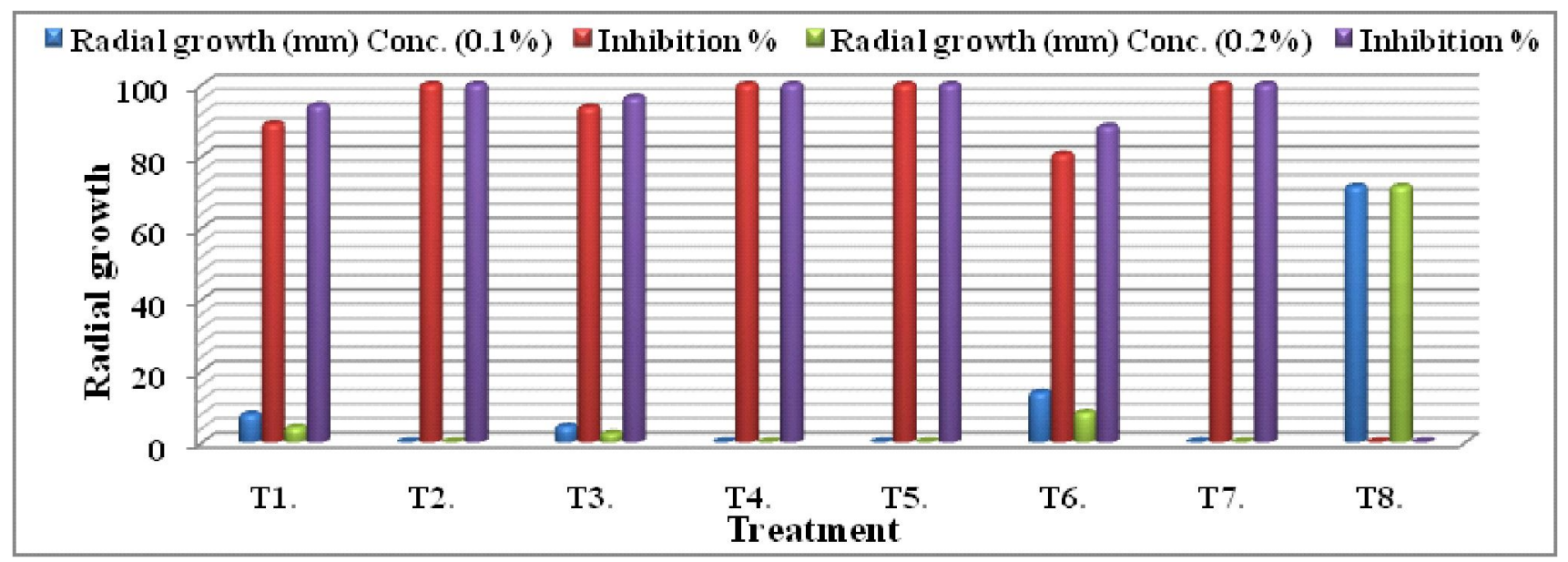

Figure 1: Efficacy of fungicides (after 4 day) at different concentrations against $R$. solani.

Table 3: Efficacy of fungicides (after 8 day) at different concentrations against $R$. solani

\begin{tabular}{|c|l|c|c|c|c|}
\hline S.No. & Fungicides & $\begin{array}{c}\text { Radial growth }(\mathbf{m m}) \\
\text { Conc. }(\mathbf{0 . 1} \%)\end{array}$ & Inhibition \% & $\begin{array}{c}\text { Radial growth (mm) } \\
\text { Conc. }(\mathbf{0 . 2} \%)\end{array}$ & Inhibition \% \\
\hline $\mathrm{T}_{1}$ & Kresoxim methyl & $11.17(19.50)$ & 87.58 & $8.64(17.09)$ & 90.40 \\
\hline $\mathrm{T}_{2}$ & Propineb & $0(0.28)$ & 100 & $0(0.28)$ & 100 \\
\hline $\mathrm{T}_{3}$ & $\begin{array}{l}\text { Tebuconazole } \\
\text { Trifloxystrobin }\end{array}$ & $8.83(17.28)$ & 90.18 & $3.17(10.24)$ & 96.47 \\
\hline $\mathrm{T}_{4}$ & Propiconazole & $0(0.28)$ & 100 & $0(0.28)$ & 100 \\
\hline $\mathrm{T}_{5}$ & Hexaconazole & $0(0.28)$ & 100 & $0(0.28)$ & 100 \\
\hline $\mathrm{T}_{6}$ & Mancozeb & $19.83(26.43)$ & 77.96 & $12.48(20.68)$ & 86.13 \\
\hline $\mathrm{T}_{7}$ & Carbendazim & $0(0.28)$ & 100 & $0(0.28)$ & 100 \\
\hline $\mathrm{T}_{8}$ & Control & $90.00(71.56)$ & - & $90.00(71.56)$ & - \\
\hline & CD $(\boldsymbol{p}=\mathbf{0 . 0 1})$ & $\mathbf{1 . 1 3}$ & $\mathbf{2 . 7 4}$ & $\mathbf{0 . 9 5}$ & $\mathbf{2 . 6 0}$ \\
\hline & C V & & & & \\
\hline
\end{tabular}




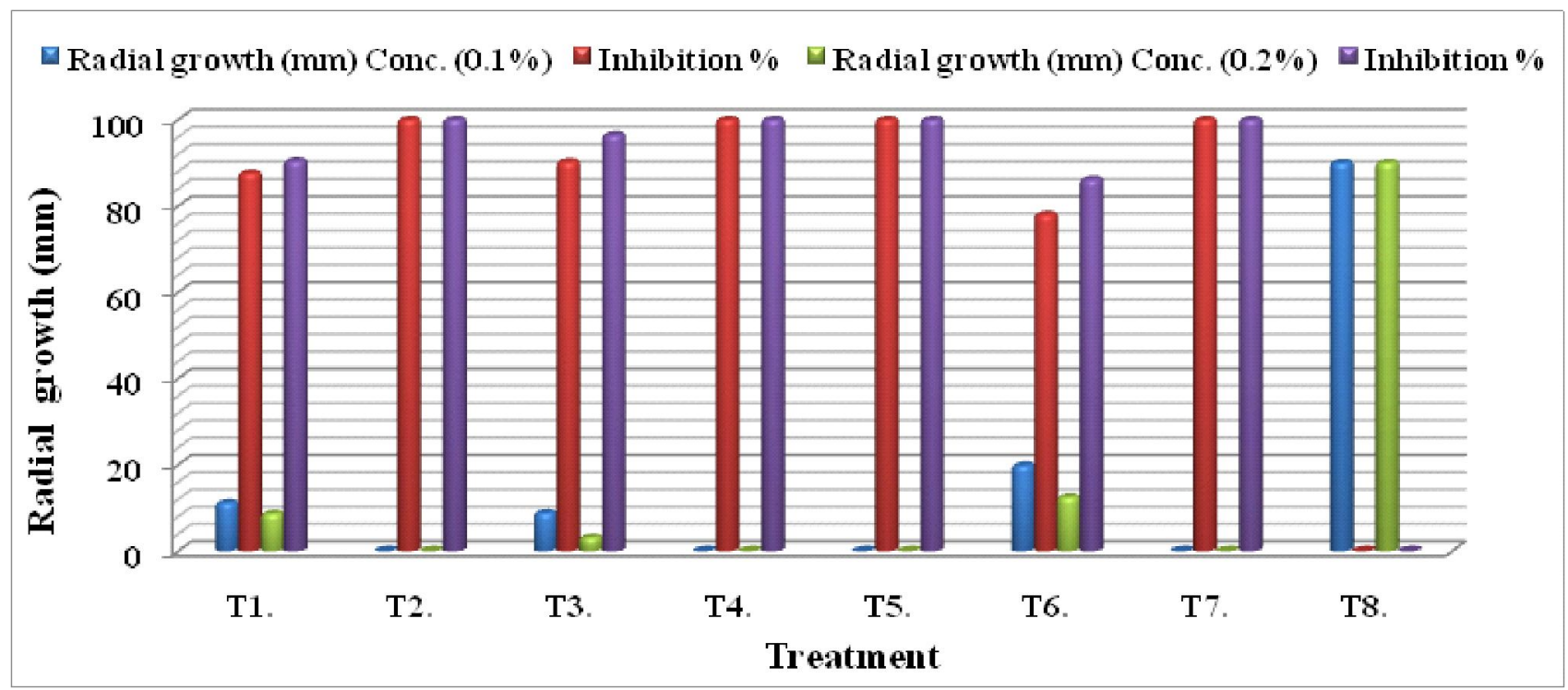

() figures in parentheses are transformed angular value.

Figure 2: Efficacy of fungicides (after 8 day) at different concentrations against $R$. solani.

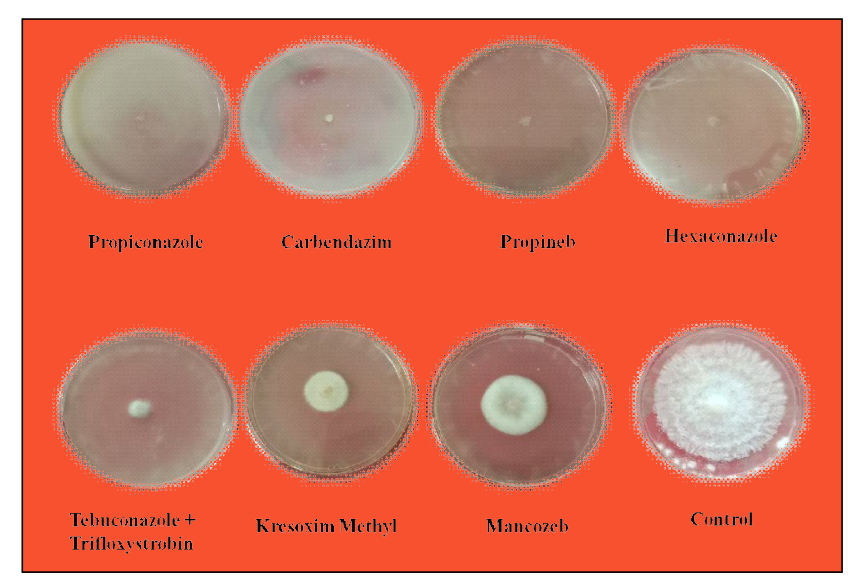

Plate 1: Effect of fungicides on the mycelia growth of $R$. solani at $0.1 \%$.

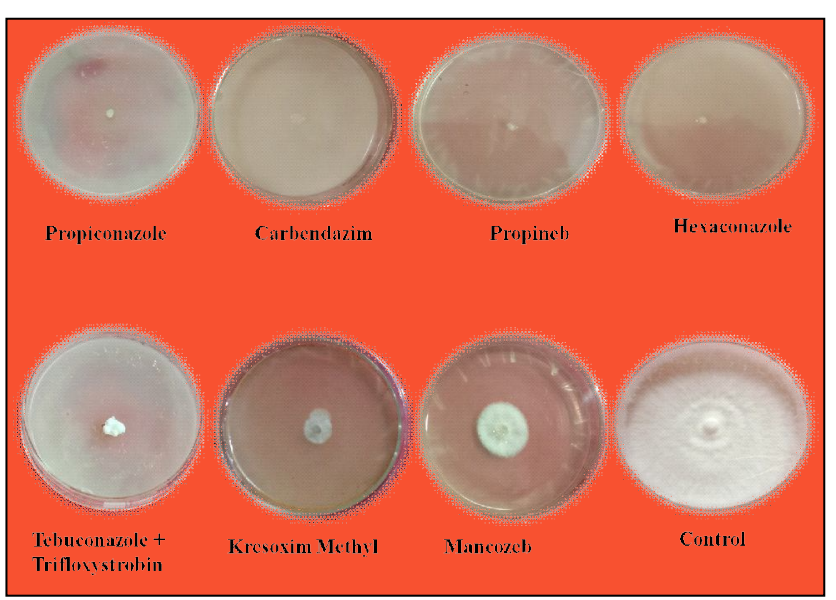

Plate 2: Effect of fungicides on the mycelia growth of $R$. solani at $0.2 \%$.

\section{Discussion}

Sheath blight disease has become a serious problem due to an intensive cultivation of rice. Present agricultural practices such as poor sanitation, reuse of irrigation water, heavy use of nitrogenous fertilizers, and high plant density have goaded the incidence of sheath blight disease in rice leading to drastic yield losses (Pramesh et al., 2016). Various strategies including newer molecules has become crucial for the sustainable management of sheath blight disease.

Results are well in agreement with the findings of Dash and Panda (1984) and Shukla et al. (1990) as they reported carbendazim was the most effective against inhibition of mycelia growth of $R$. solani (Dutta and Kalha, 2011). Gupta (2002) observed that carbendazim inhibited $95-100 \%$ of fungal growth of $R$. solani. Reddy and Murlidharan et al. (2007) have also reported that Luster 37.5 EC (flusilazole $12.5 \%$ + carbendazim 25\%) an effective against sheath blight of rice and found that spray of Luster was found superior to the spray against single straight fungicide application of carbendazim. Similar results were found by Kumar et al. (2017). Mushineni et al. (2017) evaluated various fungicides at different concentrations. Among them, tebuconazole $50 \%$ + trifloxystrobin $25 \%$ WG gave the lowest $\mathrm{ED}_{50}$ value $(0.0054 \mathrm{~g} / \mathrm{l})$ followed by the hexaconazole $5 \% \mathrm{SC}(0.005$ $\mathrm{ml} / \mathrm{l})$ and propiconazole $25 \%$ EC $(0.011 \mathrm{ml} / \mathrm{l})$. Uppala and Zhou (2018) reported fungicide propiconazole was found highly effective against the sheath blight disease.

The minimum radial growth $(8.83$ and $3.17 \mathrm{~mm})$ was recorded in (tebuconazole + trifloxystrobin), followed by kresoxim methyl (11.17 and $8.64 \mathrm{~mm})$, mancozeb (19.83, $12.48 \mathrm{~mm}$ ) and control $(90.00 \mathrm{~mm})$ while no mycelial growth was observed in propineb, propiconazole, $\mathrm{T}_{5}$ hexaconazole and carbendazim at 0.1 per cent and 0.2 per cent concentration, respectively. The best results were found after 8 day of inoculation. Maximum inhibition was recorded in propineb, propiconazole, hexaconazole and carbendazim against $R$. solani (100 per cent), followed by tebuconazole + trifloxystrobin (96.47 per cent) and kresoxim methyl (90.40 per cent). Our findings are in agreement with the findings of Kumar et al. (2017). 


\section{Conclusion}

The present study evaluated different new generation of fungicide at various concentrations in lab condition. Propiconazole, hexaconazole, propineb and carbendazim was found highly effective completely inhibited the mycelial growth of the fungus. All the remaning fungicides, i.e., kresoxim methyl $(87.58 \%, 90.40 \%)$, tebuconazole + trifloxystrobin $(90.18 \%, 96.47 \%)$ and mancozeb $(77.97 \%, 86.13 \%)$ at 0.1 and 0.2 per cent concentration, respectively. This study assists the farmer to select the fungicide which is highly effective and manage the disease rapidly and increases the yield.

\section{Acknowledgements}

The authors are thankful to Head, Department of Plant Pathology and Director Research, ANDUAT, Ayodhya for providing all facilities during this study.

\section{Conflict of interest}

The authors declare no conflict of interest related to this article.

\section{References}

Adhipathi, P.; Singh, V. and Meena, S.C. (2013). Virulence diversity of Rhizoctonia solani causing sheath blight disease in rice and its host pathogen interaction. The Bioscan., 8(3):949-952.

Chahal, K.S.; Sokhi, S.S. and Rattan, G.S. (2003). Investigations on sheath blight of rice in Punjab. Indian Phytopathol., 56:22-26.

Dash, S.C. and Panda, S. (1984). Chemical control of rice sheath blight disease. Indian Phytopathol., 37:79-82.

Delseny, M.; Salses, J.; Cooke, R.; Sallaud, C. and Regad, F. (2001). Rice genomics: Present and future. Plant Physio. Biochem., 39:323-334.

Dutta, U. and Kalha, C.S. (2011). In vitro evaluation of fungicide, botanicals and bioagents against Rhizoctonia solani causing sheath blight of rice. J. Mycopathol. Res., 49(2):333-336.

Gupta, R.P. (2002). Fungicides management of web blight of moong bean J. Mycol. Pl. Pathol., 32(1):141.

Kumar, V.; Zacharia, S.; Singh, D.; Singh, C. K.; Singh, V. K. and Singh, R. K. (2017). Ecofriendly management of sheath blight of paddy caused By $R$. solani Khun. Bull. Env. Pharmacol. Life Sci., 6(1):354-359.
Mahantesh; Singh, O.; Vishwanath and Singh, D. (2018). Efficacy of fungicides for the management of sheath blight of rice. Chem. Sci. Rev. Lett., 7(27):714-718.

Meena, S.C.; Singh, V.; Adhipathi, P. and Chand R. (2013). Screening for sheath blight resistant genotypes among mutated population of rice cv. Pusa basmati-1. The Bioscan., 8(3):919-924.

Molla, K.A.; Karmakar, S.; Molla, J.; Bajaj, P.; Varshney, R.K.; Datta, S.K. and Datta, K. (2020). Understanding sheath blight resistance in rice: The road behind and the road ahead. Plant Biotechnol. J., 18:895-915.

Muralidharan, K.; Reddy, C.S.; Krishnaveni, D. and Laha, GS. (2007). Evaluation of plant derived commercial products for blast and sheath blight control in rice. Indian Phytopathology, 56(2):151-155.

Mushineni, A.; Khalko. S. and Thapa, S. (2017). In vitro study of new generation chemicals against Rhizoctonia solani Kuhn causing sheath blight of rice. International Journal of Agriculture Sciences, 19(9):4201-4203.

Paracer, C.S. and Chahal, D.S. (1963). Sheath blight of rice caused by $R$. solani Kuhn, new record in India. Curr. Sci., 32:328-329.

Pathak, H.; Tripathi, R..; Jambhulkar, N.N.; Bisen, J.P. and Panda, B.B. (2020). Eco-regional based rice farming for enhancing productivity, profitability and sustainability, ICAR-NRRI, Cuttack, Odisha, Research Bulletin No. 22. pp:8.

Pramesh, D.; Maruti.; Muniraju, K. M.; Mallikarjun, K.; Guruprasad. G. S.; Mahantashivayogayya, K.; Reddy, B. G. M.; Gowdar, S. B. and Chethana, B. S.(2016). Bio-efficacy of a combination fungicide against blast and sheath blight diseases of paddy. Journal of Experimental Agriculture International, 14(4):1-8.

Shukla, R.P.; Singh R.K. and Dwivedi, R.S. (1990). Efficacy of fungicides against enzyme produced by rice sheath blight pathogen. Int. Rice Res. Newsl., 15:20.

Singh, A.; Chandra, R. and Bhardwaj, N. R. (2015). Evaluation of fungicides against Rhizoctonia solani causal agent of sheath blight of rice. Intl. J. App. Pure Sci. Agri., 1(8):2394-5532.

Uppal, S. and Zhou, X.G. (2018). Field efficacy of fungicides for management of sheath blight and narrow brown leaf spot of rice. Crop Protec., 104:72-77.

Vincent, J.M. (1947). Distortion of fungal hyphae in presence of certain inhibitors, 159:850.

Wu, W.; Huang, J.; Cui, K.; Nie, L. and Wang, Q. (2012). Sheath blight reduces stem breaking resistance and increases lodging susceptibility of rice plants. Field Crops Res., 128:101-108. 